\title{
Development and Verification of the Capacity Curve for Two Dimensional Reinforced Concrete Moment-Resisting Frames System under Earthquake Loading
}

\author{
Haider Ali Abass* \\ M.Sc. Student \\ Mustansiriyah University \\ College of Engineering \\ Department of Civil Engineering \\ Baghdad - Iraq \\ hiaderaabass@uomustansiriyah.edu.iq
}

\author{
Dr. Husain Khalaf Jarallah \\ Assistance Professor \\ Mustansiriyah University \\ College of Engineering \\ Department of Civil Engineering \\ Baghdad - Iraq \\ khalfdce@uomustansiriyah.edu.iq
}

\begin{abstract}
Pushover analysis is an efficient method for the seismic evaluation of buildings under severe earthquakes. This paper aims to develop and verify the pushover analysis methodology for reinforced concrete frames. This technique depends on a nonlinear representation of the structure by using SAP2000 software. The properties of plastic hinges will be defined by generating the moment-curvature analysis for all the frame sections (beams and columns). The verification of the technique above was compared with the previous study for two-dimensional frames (4-and 7-story frames). The former study leaned on automatic identification of positive and negative moments, where the concrete sections and steel reinforcement quantities the source of these moments. The comparison of the results between the two methodologies was carried out in terms of capacity curves. The results of the conducted comparison highlighted essential points. It was included the potential differences between default and user-defined hinge properties in modeling. The effect of the plastic hinge length and the transverse of shear reinforcement on the capacity curves was also observed. Accordingly, it can be considered that the current methodology in this paper more logistic in the representation of two and three-dimensional structures.
\end{abstract}

Keywords: Pushover Analysis, Plastic Hinge Length, Nonlinear Hinge Properties, PerformanceBased Design.

*Corresponding author

Peer review under the responsibility of University of Baghdad.

https://doi.org/10.31026/j.eng.2021.06.06

2520-3339 () 2019 University of Baghdad. Production and hosting by Journal of Engineering.

This is an open access article under the CC BY4 license http://creativecommons.org/licenses/by/4.0/).

Article received: 10/2/2021

Article accepted: 27/3/2021

Article published:1/6/2021 


\title{
التظوير والتحقق من منحنى المقاومة لأنظمة الهياكل المقاومة للعزوم ثنائية الأبعاد تحت الاحمال الزلزالية
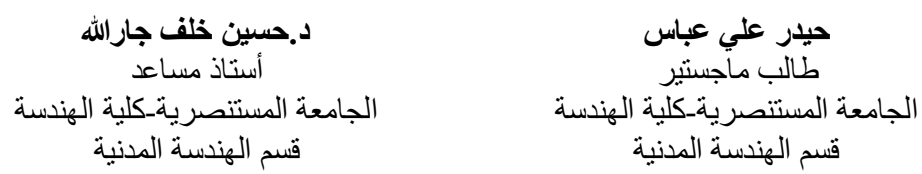

\begin{abstract}
الخلاصة
تحليل الدushover هي أداة فعالة للتقييم الزلزالي للمباني تحت تأثير الزلازل القوية. يهدف هذا البحث من التطوير والتحقق

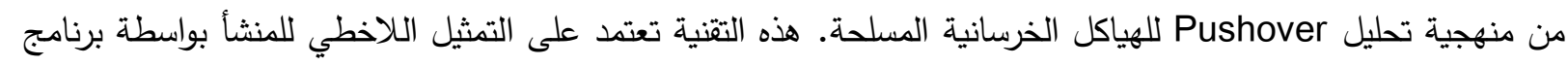

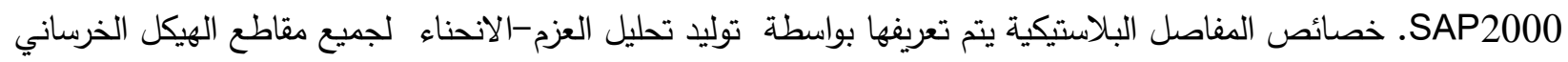

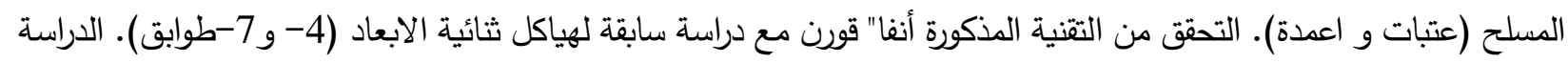

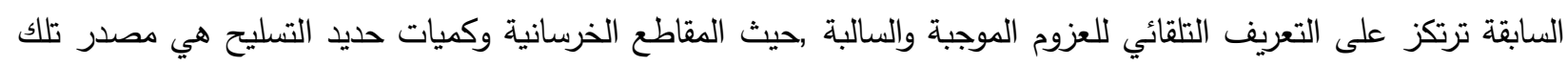
العزوم. المقارنة في النتائج بين المنهجيتين كانت بحدود منحنى المقاومة. أبرزت نتائج المقارنة التي أجريت نقاطا" هامة. تضمنت

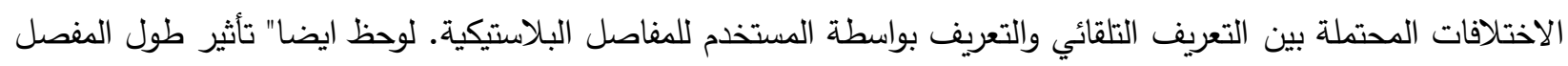

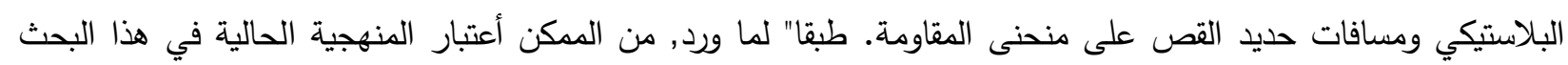
منطقية أكثر في تمثيل المنشأت الثنائية و الثلاثية الابعاد. الكلمات الرئيسية: تحليل Pushover, طول المفصل اللدن,خصائص المفاصل اللاخطية, التصميم المستتد على الاداء.
\end{abstract}

\section{INTRODUCTION}

In recent years, nonlinear static analysis has gained significant research attention within the earthquake engineering community. Their main objective is to explain the nonlinear capacity of the buildings when subjected to earthquake loading. Two methods for investigating inelastic seismic performance are available. One is the nonlinear time history analysis, and another is a nonlinear static analysis called "pushover analysis". The nonlinear time history analysis can be divided into two methods. One is based on the dynamic response of an equivalent single degree of freedom system derived from a multi-degree of freedom (MDOF) system (Fajfar, 2000) (Mahmoud and Al-Baghdadi, 2018). The other is based on the equivalent response directly obtained from the nonlinear dynamic response of a MDOF system (Lee et al., 2006). Static pushover analysis has been the preferred method for seismic performance evaluation. Pushover hereinafter is not a recent development, and its genesis traced back to the 70's decade (Panandikar and Narayan, 2015). The static pushover analysis can also be divided into two methods. One is based on the first-mode pushover analysis (Chopra and Goel, 2014). The other is based on the modal pushover analysis (MPA), where higher mode effects are taken into account (Seneviratna and Krawinkler, 1997). The use of linear elastic methods appears to be inappropriate and common in new design situations. For these purposes, many codes and guidelines, such as the Applied Technology Council guideline (ATC-40,1996) and Federal Emergency Management Agency guideline (FEMA-356,2000), are recommend using pushover analysis to assess structural behavior under seismic activity. Pushover analysis is based on the assumption that the dynamic response of the structure is controlled by the fundamental elastic mode, which is the case for most 
regular buildings (Elnashai and Sarno, 2008). Some programs (i.e., SAP2000) have implemented the pushover analysis with nonlinear geometrical by generating default or by user-defined hinge properties. In some cases, the default hinges properties are used because they are easy. This paper aims to develop and verify the pushover analysis methodology for reinforced concrete frames. The plastic hinge properties relied on the moment-curvature analysis. The moment-curvature analysis was generated by using section designer in SAP2000 software for all the frame sections (beams and columns).

\section{THE RESEARCH SIGNIFICANCE}

This research explains the following important points:

- Clarify the sensitivity of pushover analysis due to the definition of plastic hinge properties by generating the moment-curvature analysis of the frame sections.

- Show the differences between the default hinge and the user-defined hinge properties within capacity curve limits.

- Illustrate the effect of plastic hinge length on the capacity curves using two different hinge length expressions.

- Explain the effect of the transverse reinforcement spacing on the capacity curves by using three different spacing $(S=100,150$, and 200mm).

\section{STATIC PUSHOVER ANALYSIS}

Pushover analysis is stated as a nonlinear analysis in which the nonlinear load-deformation characteristics are determined directly by incorporating the mathematical model of the building frame (ATC-40,1996). It is carried out by applying an assumed distribution of lateral loads over the height of the structure (Hede and Babunarayan, 2013). The lateral loads increase monotonically from zero to the ultimate level, which corresponds to the initial collapse of the structure. Pushover analysis evaluates the structural performance by computing the force, drift capacity, and seismic demand. The analysis accounts for material inelasticity, geometrical nonlinearity, and the redistribution of internal forces (Durgesh, 2005). The seismic demand parameters are element deformations, element forces, global displacement, story drift, and story forces (Chopra and Goel,2002) (Erduran and Yakut, 2007). During the analysis, the gravity load remains constant. The system of solving equations is

$k_{i} \Delta y_{i}=\Delta F_{i}$

Where $[\mathrm{K}]$ is the tangent stiffness matrix; $\left[\Delta y_{i}\right]$ is an incremental vector of displacement and $\left[\Delta F_{i}\right]$ is the vector of incremental effective dynamic forces. Pushover analysis is very useful in assessing the structure's capacity as represented by the base shear versus roof displacement (Bagchi, 2001), as shown in Fig.1. 


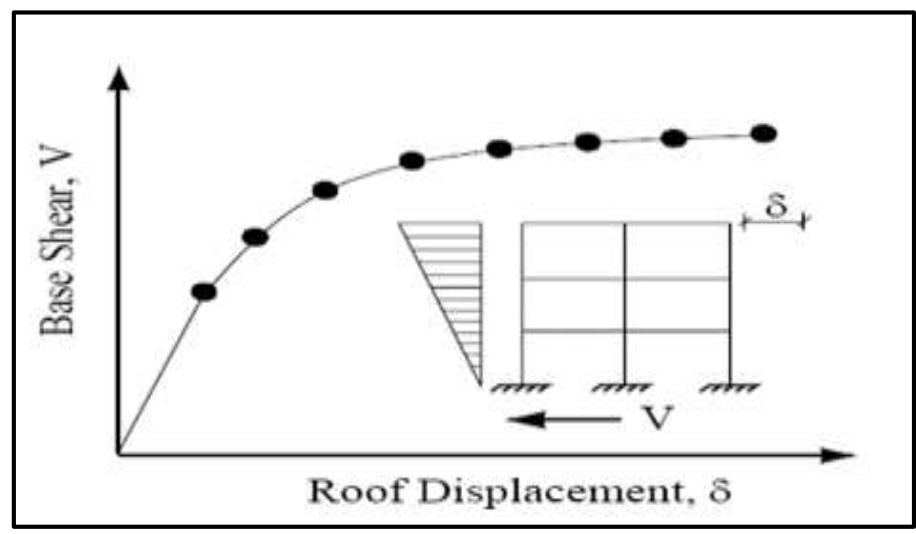

Figure 1. Pushover Curve of a Structure (Bagchi, 2001).

Pushover analysis is practical in estimating the maximum rotation and ductility of the elements, plastic hinges distribution at the ultimate load, damage distribution in the structures at the ultimate load, and yield lateral resistance determination of the structures (Altelbani, 2015).

\section{VERIFICATION OF PUSHOVER ANALYSIS}

Two-dimensional frame structures were modeled and analyzed to verify the performance and the applicability of the pushover method. The analysis procedure was not restrained within the pushover results only. Still, it also included a comparative study between the current pushover results and the pushover results obtained by (Inel and Ozmen, 2006) study. SAP2000 V22 software was used to validate the current methodology, which differs from (Inel and Ozmen, 2006) methodology. Pushover analysis results in the current study depend on the definition of the plastic hinge properties for beams and columns by using the moment-curvature analysis.

\subsection{General Structures Description}

In this study, the same buildings in (Inel and Ozmen, 2006) study will be used. 4-and 7-story buildings are $16 \mathrm{~m}$ by $12 \mathrm{~m}$ in the plan Fig.2. Typical floor to floor is $2.8 \mathrm{~m}$. The interior frame shown in Fig.2 represents 2-D models of these buildings. Two frames are measured to reflect low and medium-rise RC buildings. Beam-column systems without shear walls are the structural system of the frames. 


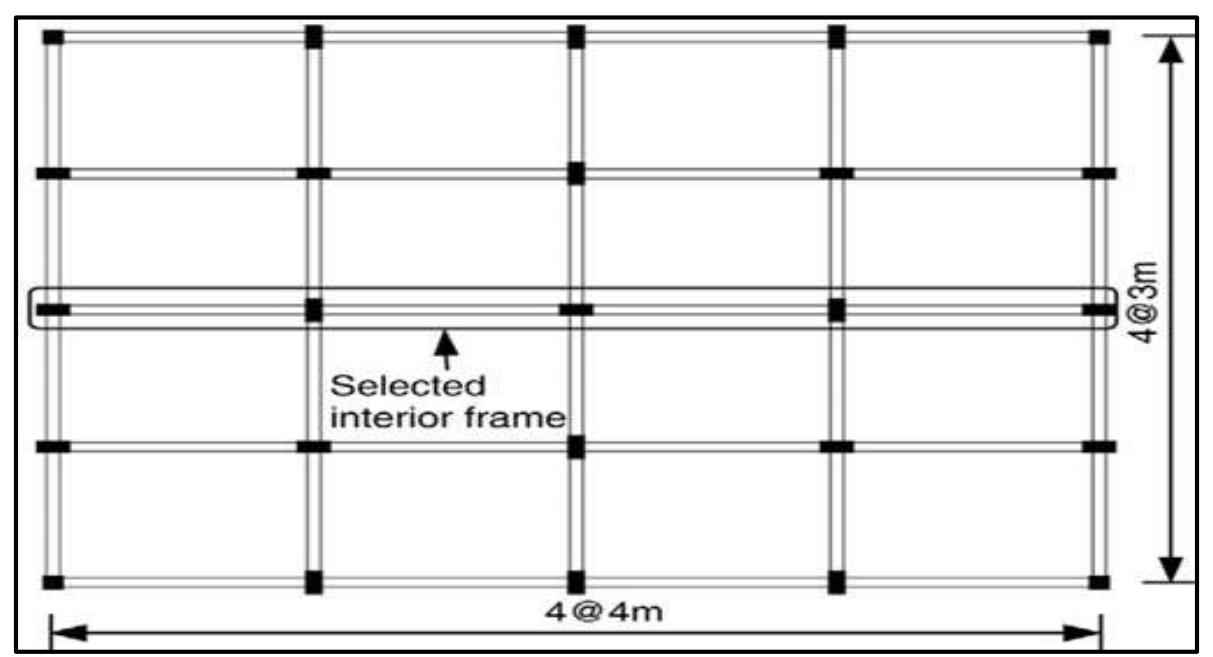

Figure 2. (4) and (7) story buildings plan view (Inel and Ozmen, 2006).

\subsection{Material Properties}

The properties of concrete and steel reinforcement are obtained from the available information (Inel and Ozmen, 2006). The specified material strength can be lower than the actual (expected) strength of the in-situ material, so the "expected" values are often greater than the "specified" values due to the inherent strength and strength gained over time in the original material. According to the American Society of Civil Engineering guideline (ASCE/SEI 41-13) and Federal Emergency Management Agency guideline (FEMA-273, 1997), the translate factors from lower bound "specified" value to "expected" value presented in Table 1.

Table 1. Material Properties.

\begin{tabular}{|c|c|c|c|c|c|c|c|}
\hline Material & \multicolumn{4}{|c|}{ Concrete } & \multicolumn{3}{c|}{ Steel Reinforcing } \\
\hline Member & Grade & $\begin{array}{c}\text { Specified } \\
\text { cylinder } \\
\text { strength } \\
(\mathrm{MPa})\end{array}$ & $\begin{array}{c}\text { Translate } \\
\text { Factors to } \\
\text { Expected } \\
\text { cylinder } \\
\text { strength }\end{array}$ & $\begin{array}{c}\text { Expected } \\
\text { cylinder } \\
\text { strength } \\
(\mathrm{MPa})\end{array}$ & $\begin{array}{c}\text { Specified } \\
\text { yield } \\
\text { strength } \\
\text { (Mpa) }\end{array}$ & $\begin{array}{c}\text { Translate } \\
\text { Factors to } \\
\text { Expected } \\
\text { yield } \\
\text { strength }\end{array}$ & $\begin{array}{c}\text { Expected } \\
\text { yield strength } \\
\text { (Mpa) }\end{array}$ \\
\hline Beam & $\mathrm{C} 16$ & 16 & 1.5 & 24 & 220 & 1.25 & 275 \\
\hline Column & $\mathrm{C} 16$ & 16 & 1.5 & 24 & 220 & 1.25 & 275 \\
\hline
\end{tabular}

\subsection{Structural modeling approach}

Stiffness of the cracked section (ATC-40, 1996) was used to model the structures' initial stiffness.

Table 2 presents member stiffness used in this study. 
Table 2. Initial Stiffness of Elements.

\begin{tabular}{|c|c|c|c|}
\hline Elements & $\begin{array}{c}\text { Flexural } \\
\text { rigidity }\end{array}$ & $\begin{array}{c}\text { Shear } \\
\text { rigidity }\end{array}$ & $\begin{array}{c}\text { Axial } \\
\text { rigidity }\end{array}$ \\
\hline Beams & $0.5 \mathrm{E}_{\mathrm{c}} \mathrm{I}_{\mathrm{g}}$ & $0.4 \mathrm{E}_{\mathrm{c}} \mathrm{A}_{\mathrm{w}}$ & $\mathrm{E}_{\mathrm{c}} \mathrm{A}_{\mathrm{g}}$ \\
\hline Columns & $0.7 \mathrm{E}_{\mathrm{c}} \mathrm{Ig}$ & $0.4 \mathrm{E}_{\mathrm{c}} \mathrm{A}_{\mathrm{w}}$ & $\mathrm{E}_{\mathrm{c}} \mathrm{A}_{\mathrm{g}}$ \\
\hline
\end{tabular}

The buildings were designed based on the Earthquake Code (Turkish Earthquake Code, 1975), considering both gravity and seismic loads (a design ground acceleration of $0.4 \mathrm{~g}$ and soil class Z3), which is similar to class C soil (FEMA-356, 2000).

\subsubsection{Details of 4- Story Building}

The 4-story frame is $11.2 \mathrm{~m}$ in elevation. According to (Intel and Ozmen, 2006) study, all the beams are 200*500 $\mathrm{mm}$ in dimensions. Fig. 3 and Fig. 4 represent the typical layout and the reinforcement ratio and columns details, respectively. The reinforcement ratio was calculated according to American Concrete Institute Code (ACI-318), as follows:

$$
\rho=A s / b d
$$

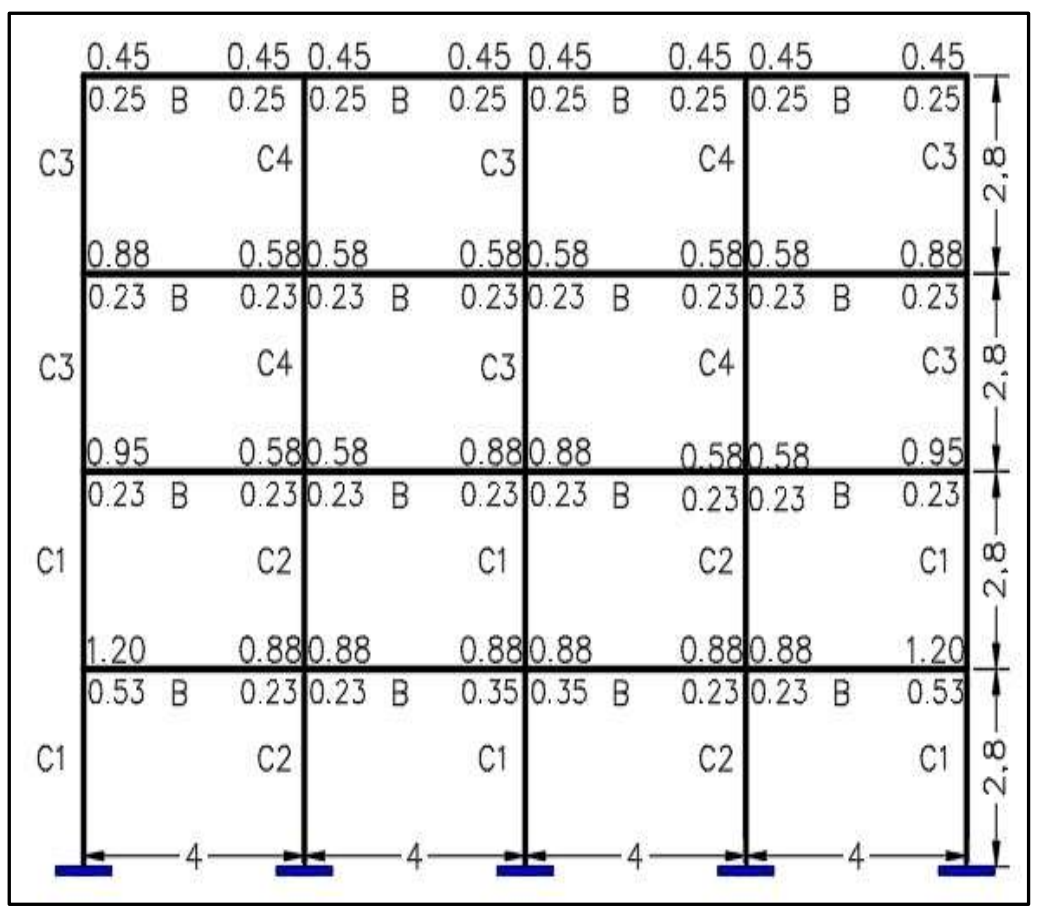

Figure 3. Typical 4-Story Frames Layout (All Dimensions in meter unit). 


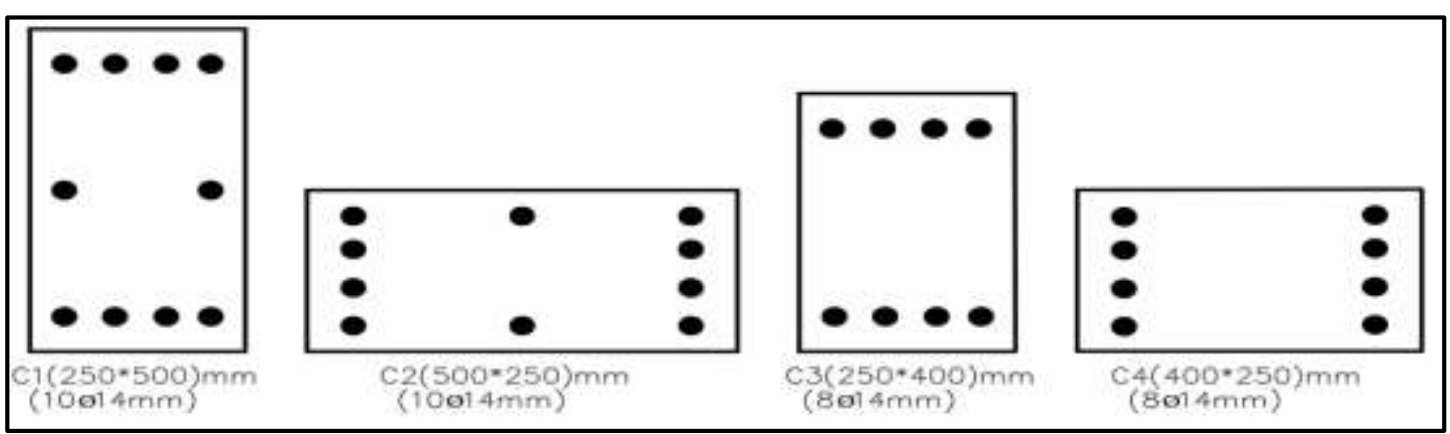

Figure 4. 4-story Columns Details.

\subsubsection{Details of 7- Story Building}

The 7- story building is $19.6 \mathrm{~m}$ in elevation. According to (Inel and Ozmen, 2006) study, all the beams are $250 * 600 \mathrm{~mm}$ in dimensions. Fig. 5 and Fig. 6 represent the typical layout and the reinforcement ratio and columns details, respectively.

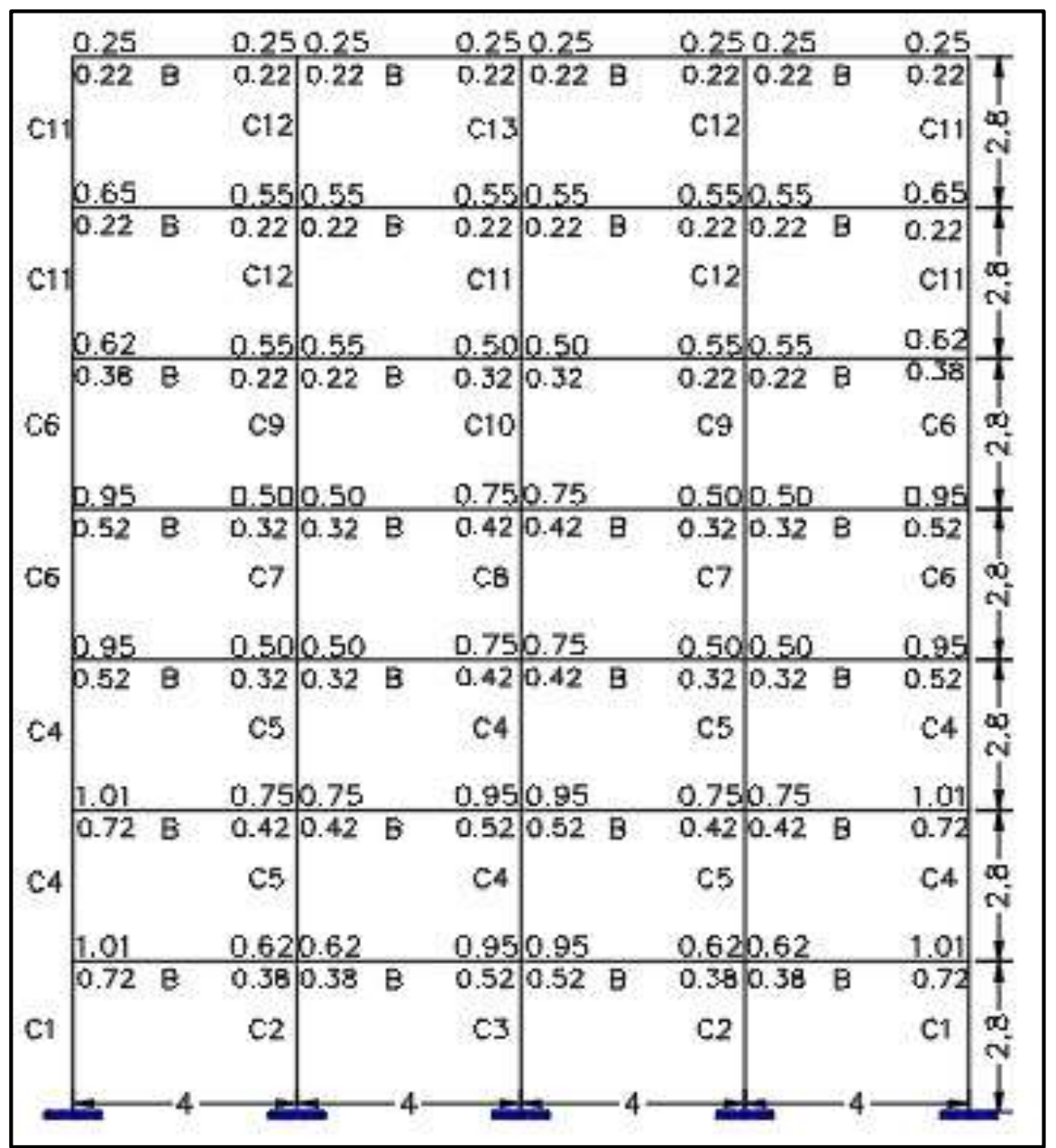

Figure 5. Typical 7-story Frame Layout. 


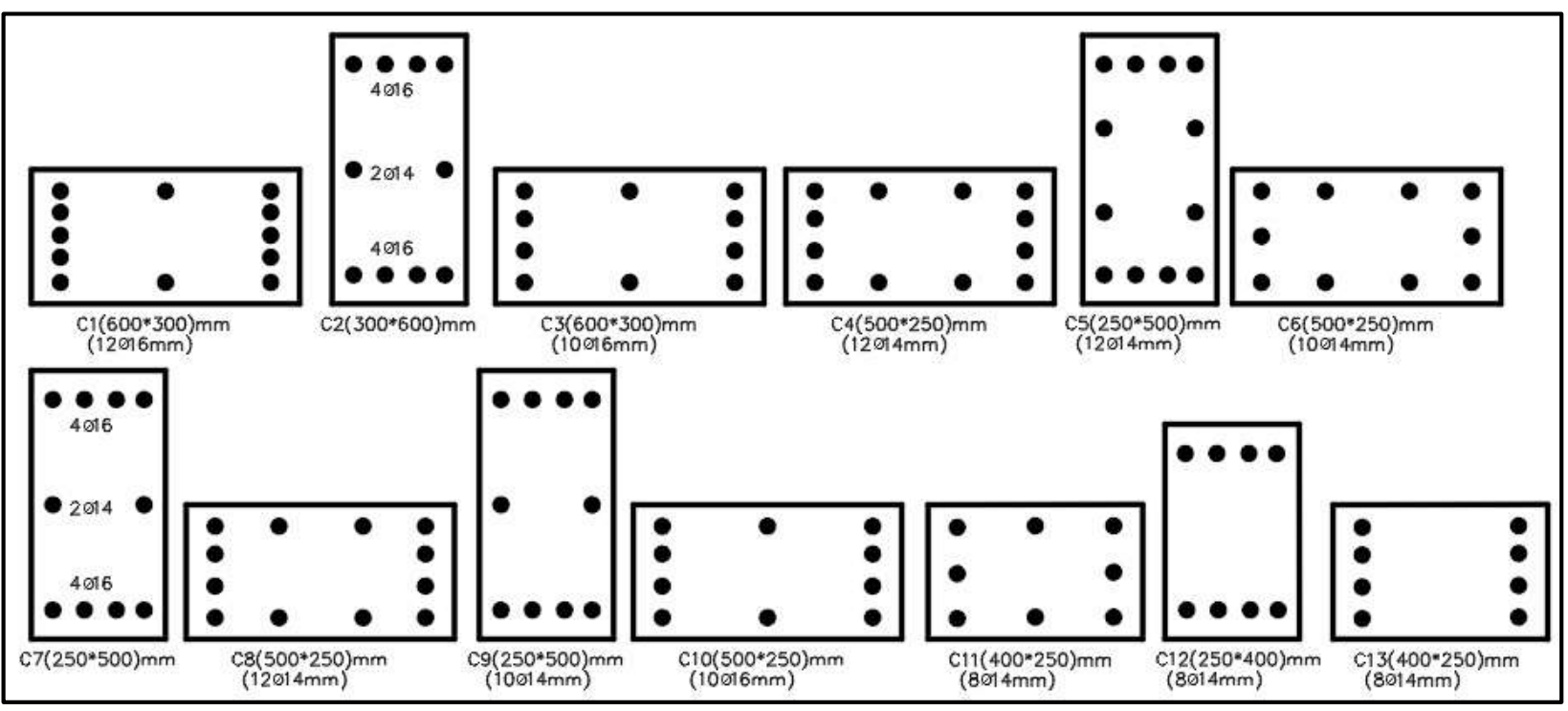

Figure 6. 7-story Columns Details.

\subsection{Validation of Dynamic Characteristics}

According to (Inel and Ozmen, 2006) study, a 4-story frame has a dead load and (30\%) of live loads as participating loads equal to $1976 \mathrm{KN}$ and $360 \mathrm{KN}$, respectively. To verify (Inel and Ozmen, 2006) study, model analysis was performed. The current study was implemented by SAP2000 software. It shows that the current findings of the study are very close to the study being investigated. The resulting natural periods for these studies are presented in Table 3.

Table 3. Dynamic characteristics of the 4-story frame.

\begin{tabular}{|c|c|c|}
\hline \multirow{2}{*}{ Model No. } & \multicolumn{2}{|c|}{ Periods (sec) } \\
\cline { 2 - 3 } & $\begin{array}{c}\text { Intel and Ozmen } \\
\text { study }\end{array}$ & Current study \\
\hline 1 & 0.755 & 0.7558 \\
\hline 2 & 0.250 & 0.245 \\
\hline 3 & 0.147 & 0.134 \\
\hline
\end{tabular}

The 7- story frame has a dead load and (30\%) of live loads as participating loads equal to 3807 $\mathrm{KN}$ and $640 \mathrm{KN}$, respectively. The current study shows that the current findings of the study are close to the study being investigated too. The resulting natural periods for these studies are presented in Table 4.

Table 4. Dynamic characteristics of the 7-story frame.

\begin{tabular}{|c|c|c|}
\hline Model No. & \multicolumn{2}{|c|}{ Periods (sec) } \\
\cline { 2 - 3 } & $\begin{array}{c}\text { Intel and Ozmen } \\
\text { study }\end{array}$ & Current study \\
\hline 1 & 0.965 & 0.990 \\
\hline 2 & 0.345 & 0.336 \\
\hline 3 & 0.209 & 0.1945 \\
\hline
\end{tabular}




\subsection{Modeling of Nonlinear Plastic Hinges}

A summary of how material nonlinearity has been given in software models SAP2000 is presented in this research. The models used to establish nonlinear moment-curvature relationships for the members supposed to be in the plastic range. Material nonlinearity can be modeled by attachment elements or discrete, lumped plasticity hinges in SAP2000 software.

\subsubsection{Models of Moment-Curvature Analysis}

The Section Designer of SAP2000 software is used to measure the moment-curvature relationships for beams and columns. The material properties were first described based on expected materials when modeling a given cross-section. In a current study, the following assumptions were used to obtain the moment-curvature curves:

- Depending on the expected material properties, the 28-day compressive strength of f'c for confined concrete (core) and unconfined concrete (concrete cover) was $24 \mathrm{MPa}$.

- The concrete models were assigned as Mander models (Mander, 1984) for confined concrete and the typical steel stress-strain model with strain hardening. (Mander, et al., 1984) have proposed a unified stress-strain approach for confined concrete Fig. 7.

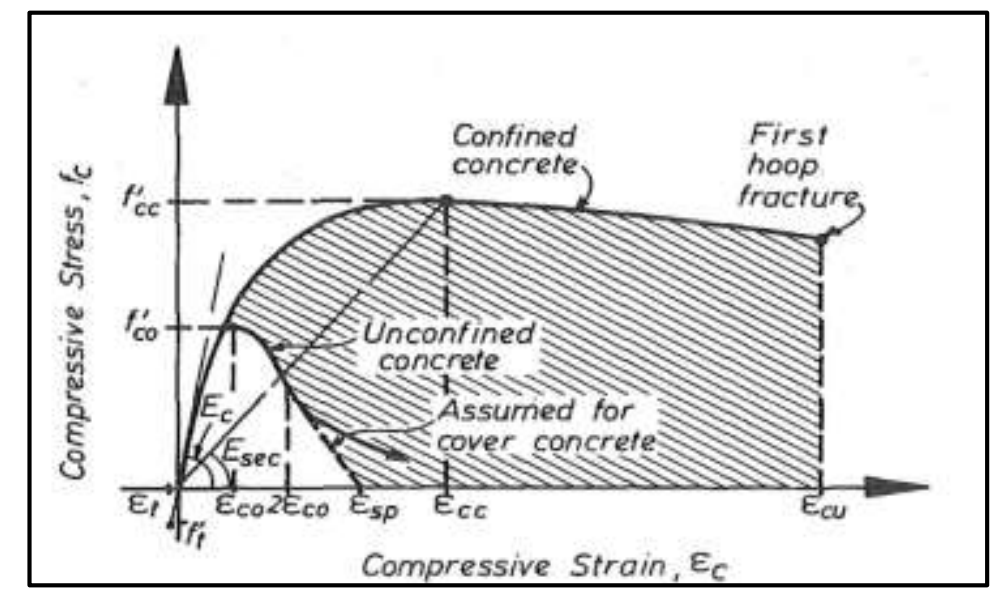

Figure 7. Stress-Strain Model Proposed for Monotonic Loading of Confined and Unconfined Concrete (Mander, et al., 1984).

- The ultimate compression strain $\varepsilon_{\mathrm{cu}}$ determined using Eq.2. In this study, the ultimate strain limit is assumed to be 0.05 . The ultimate strain range from 0.012 to 0.05 (Priestley et al., 1996).

$\varepsilon_{c u}=0.004+\frac{1.4 \rho_{s} f_{y h} \varepsilon_{s u}}{f_{c c}}$

\subsubsection{Results of Moment-Curvature}

The moment-curvature analysis result of the beams sections for 4- story and 7- story performed by using Section Designer in SAP2000. The moment-curvature relationships were linearly idealized (Bolander, 2014) (Kasimzade, et al., 2020). According to (Inel and Ozmen, 2006) study, three cases for transverse reinforcement spacing, $S=100 \mathrm{~mm}, S=150 \mathrm{~mm}$, and $S=200 \mathrm{~mm}$. Fig.8 represents the moment curvature for positive and negative regions and different transverse reinforcement spacing. 

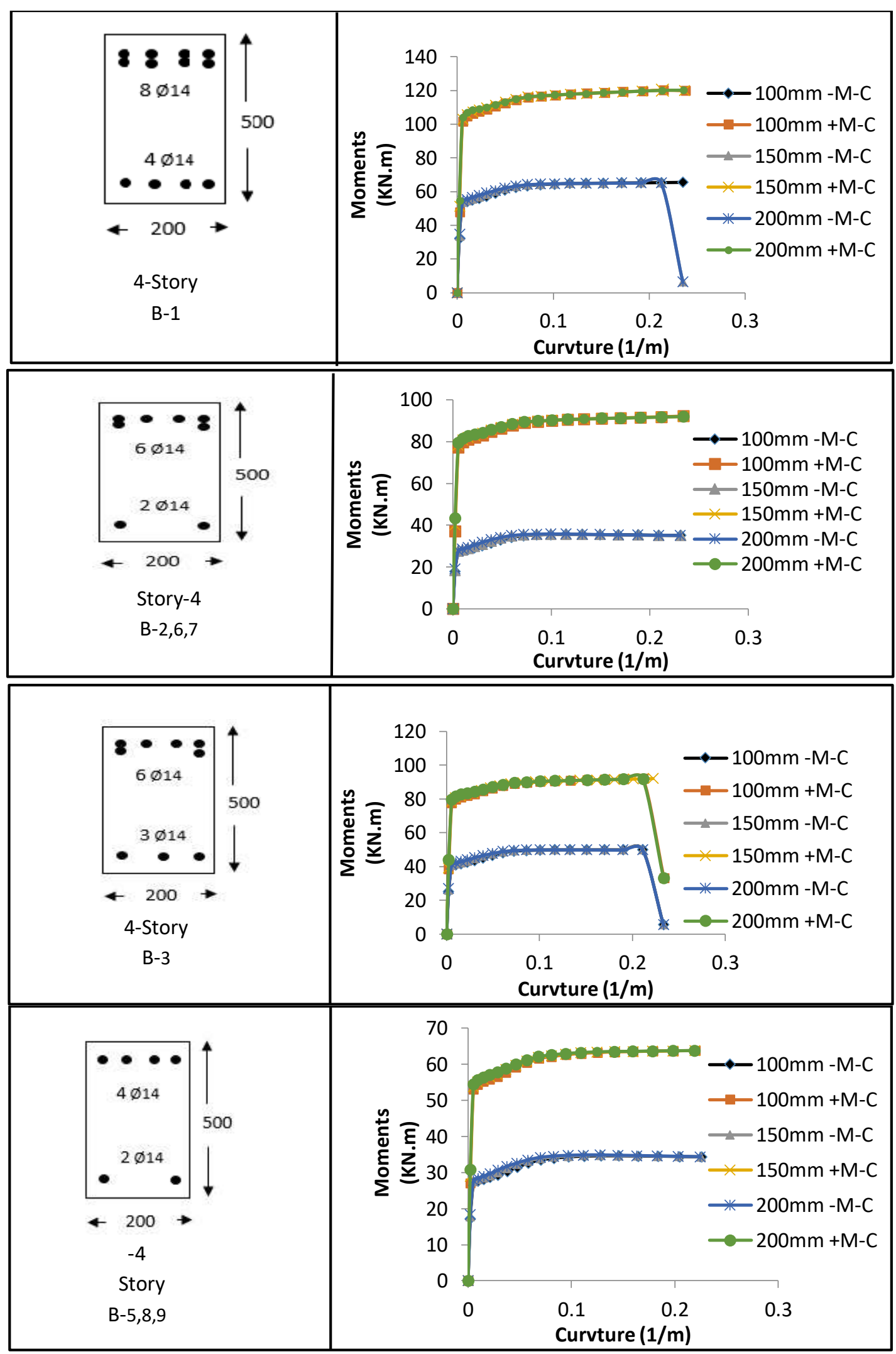

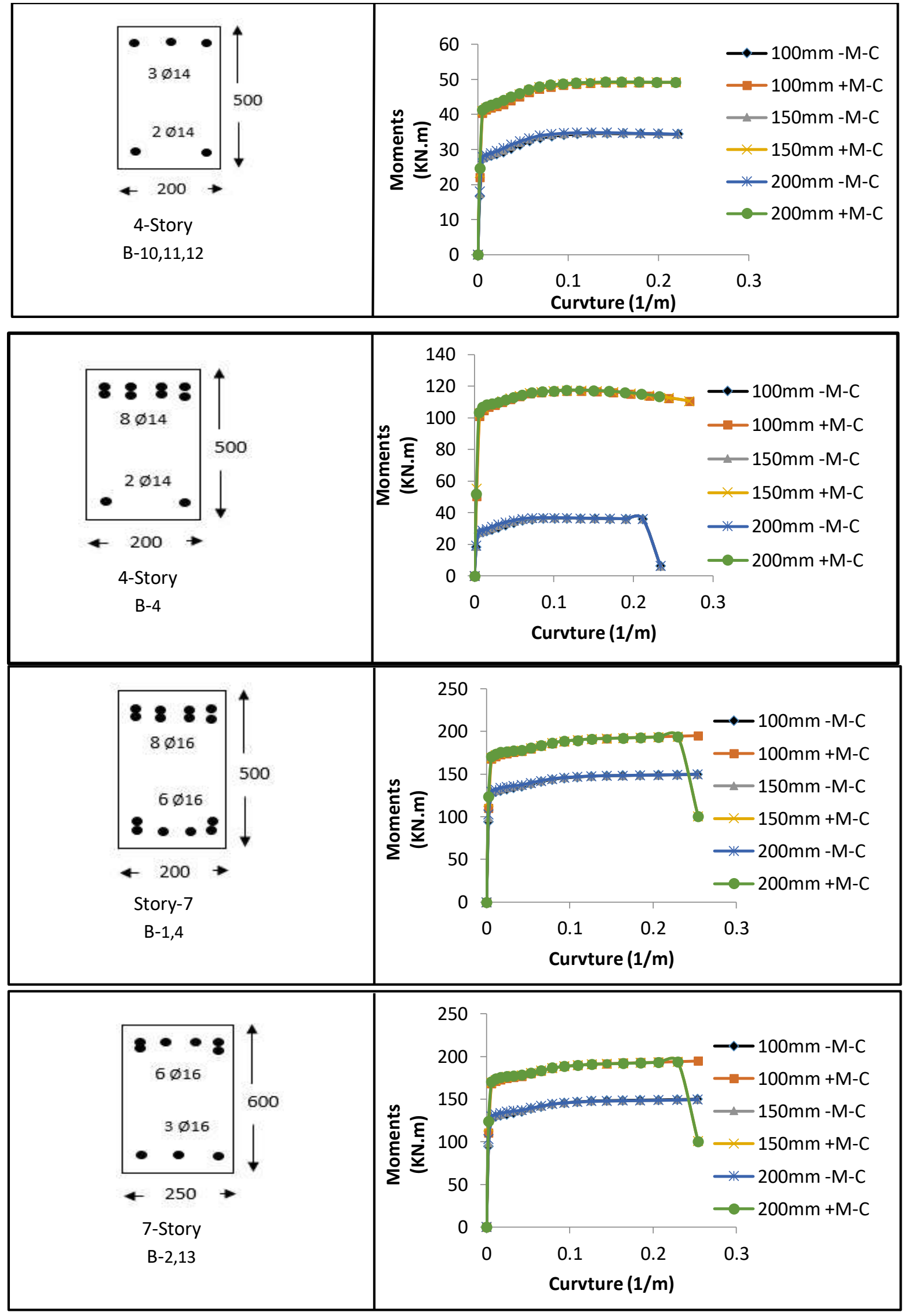
$\begin{array}{lllll}\text { Number } 6 & \text { Volume } 27 & \text { June } 2021 & \text { Journal of Engineering }\end{array}$

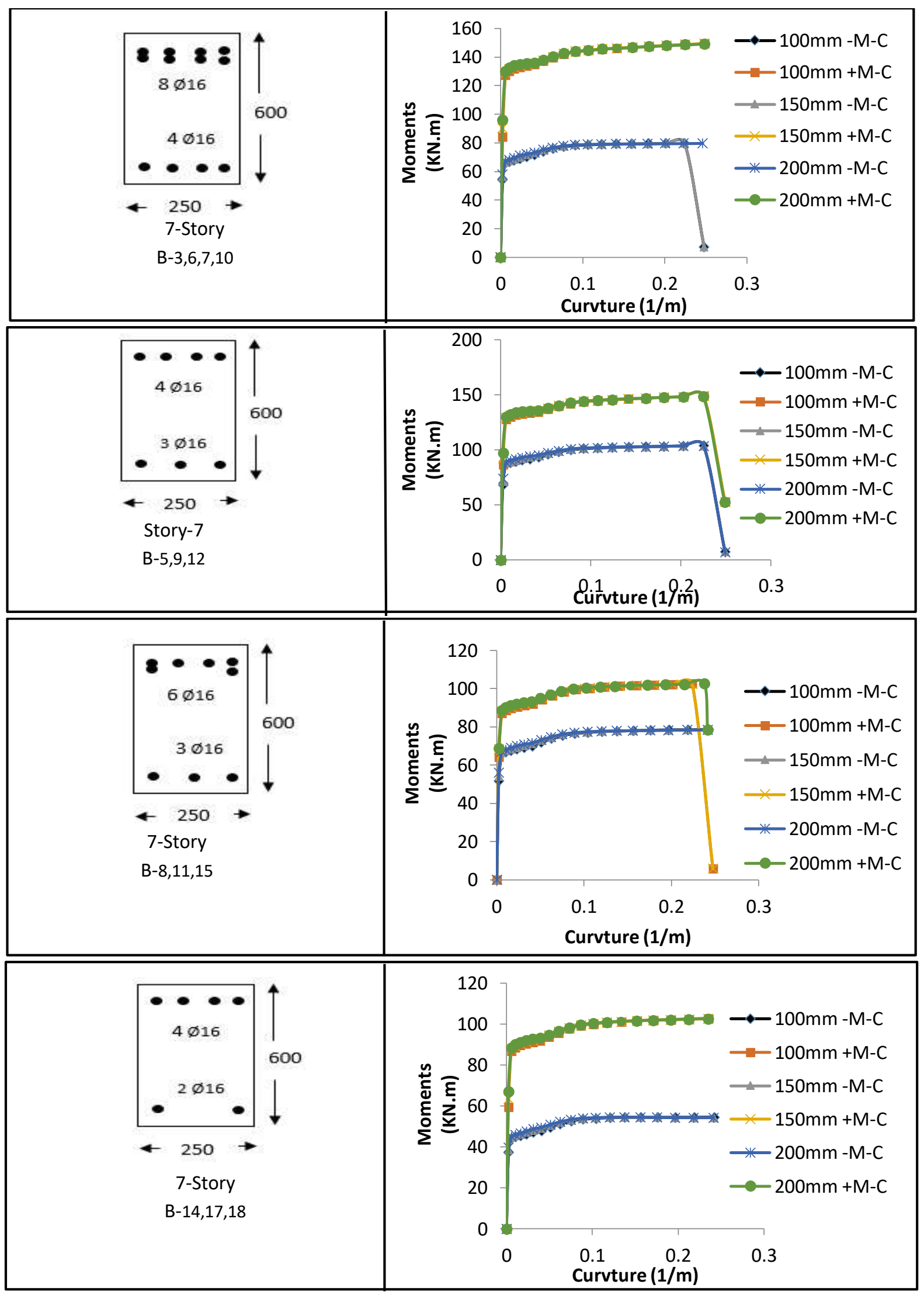


$\begin{array}{lllll}\text { Number } 6 & \text { Volume } 27 & \text { June } 2021 & \text { Journal of Engineering }\end{array}$

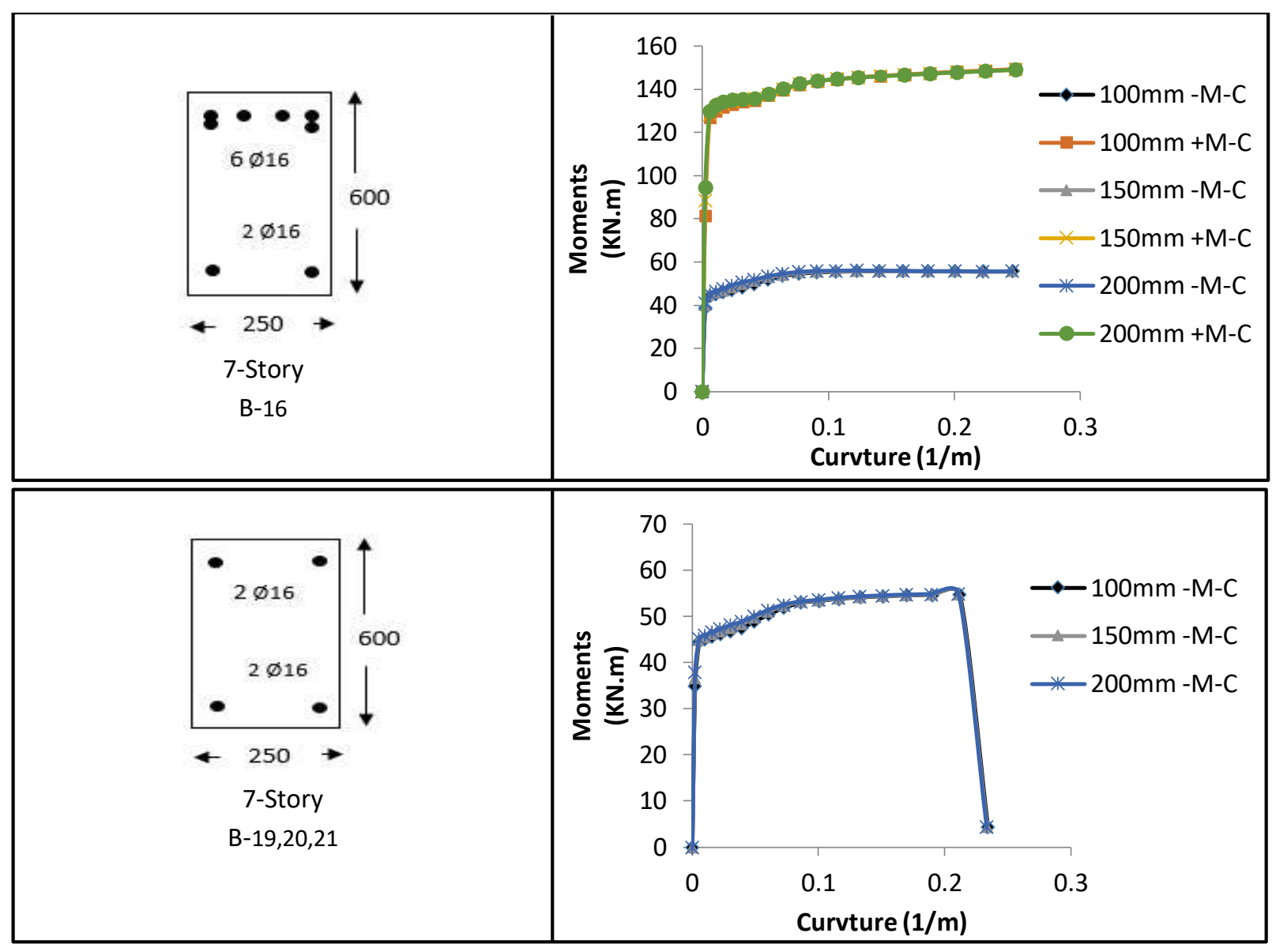

Figure 8. 4 and 7-story moment-curvature relationship. 
Table 5. Moment-Curvature Values for 4-and 7 story frames.

\begin{tabular}{|c|c|c|c|c|c|c|c|c|c|c|c|}
\hline \multicolumn{6}{|c|}{ 4-Story Moment-Curvature } & \multicolumn{6}{|c|}{ 7-Story Moment-Curvature } \\
\hline \multirow[t]{2}{*}{ Tag } & \multirow{2}{*}{$\begin{array}{l}\text { Hoop } \\
\text { space } \\
(\mathrm{mm})\end{array}$} & \multicolumn{2}{|c|}{$\begin{array}{c}\text { Yield } \\
\text { Moment } \\
\text { (KN.m) }\end{array}$} & \multicolumn{2}{|c|}{$\begin{array}{l}\text { Yield Curvature } \\
\qquad(1 / \mathrm{m})\end{array}$} & \multirow[t]{2}{*}{ Tag } & \multirow{2}{*}{$\begin{array}{l}\text { Hoop } \\
\text { space } \\
(\mathrm{mm})\end{array}$} & \multicolumn{2}{|c|}{$\begin{array}{c}\text { Yield } \\
\text { Moment } \\
\text { (KN.m) }\end{array}$} & \multicolumn{2}{|c|}{$\begin{array}{c}\text { Yield } \\
\text { Curvature } \\
(1 / \mathrm{m})\end{array}$} \\
\hline & & Bottom & Top & Bottom & Top & & & Bottom & Top & Bottom & Top \\
\hline \multirow{3}{*}{ B-1 } & 100 & 39.87 & 81.1 & 3.478 & 4.387 & \multirow[t]{3}{*}{ B-1,4 } & 100 & 99.75 & 123.5 & 3 & 3.26 \\
\hline & 150 & 40.33 & 79 & 3.395 & 4.1 & & 150 & 102.86 & 127.4 & 2.92 & 3.13 \\
\hline & 200 & 40.92 & 78.2 & 3.314 & 3.868 & & 200 & 105.94 & 131.5 & 2.85 & 3.025 \\
\hline \multirow{3}{*}{$\begin{array}{c}\text { B- } \\
2,6,7\end{array}$} & 100 & 20.64 & 60.9 & 3.213 & 4.241 & \multirow[t]{3}{*}{$\mathrm{B} 2,13$} & 100 & 55.44 & 94.1 & 2.75 & 3.21 \\
\hline & 150 & 20.98 & 59.6 & 3.153 & 3.95 & & 150 & 57.15 & 97.67 & 2.69 & 3.06 \\
\hline & 200 & 21.35 & 59.3 & 3.1 & 3.72 & & 200 & 58.48 & 101.3 & 2.63 & 2.95 \\
\hline \multirow[t]{3}{*}{ B-3 } & 100 & 30.29 & 60.3 & 3.387 & 4.12 & \multirow{3}{*}{$\begin{array}{c}\text { B-3,6, } \\
7,10\end{array}$} & 100 & 72.06 & 121.3 & 2.82 & 3.36 \\
\hline & 150 & 30.70 & 60.9 & 3.30 & 3.9 & & 150 & 74.15 & 125.3 & 2.75 & 3.20 \\
\hline & 200 & 31.20 & 59.3 & 3.23 & 3.67 & & 200 & 76.18 & 129.5 & 2.70 & 3.07 \\
\hline \multirow[t]{3}{*}{ B-4 } & 100 & 20.72 & 76 & 3.18 & 4.5 & \multirow{3}{*}{$\begin{array}{c}\text { B-8, } \\
11,15\end{array}$} & 100 & 53.66 & 68.20 & 2.80 & 2.97 \\
\hline & 150 & 21.06 & 75.2 & 3.13 & 4.2 & & 150 & 55.40 & 70.97 & 2.72 & 2.86 \\
\hline & 200 & 21.44 & 79.3 & 3.08 & 4 & & 200 & 57.1 & 71.53 & 2.65 & 2.76 \\
\hline \multirow{3}{*}{$\begin{array}{c}\text { B- } \\
5,8,9\end{array}$} & 100 & 20.56 & 41.3 & 3.26 & 3.82 & \multirow[t]{3}{*}{ B-13 } & 100 & 55.45 & 94.08 & 2.75 & 3.21 \\
\hline & 150 & 20.87 & 41.1 & 3.18 & 3.63 & & 150 & 57.15 & 97.67 & 2.68 & 3.06 \\
\hline & 200 & 21.2 & 41.1 & 3.1 & 3.46 & & 200 & 58.47 & 101.3 & 2.63 & 2.95 \\
\hline \multirow{3}{*}{$\begin{array}{l}\text { B10, } \\
11,12\end{array}$} & 100 & 20.55 & 30.7 & 3.3 & 3.59 & \multirow{3}{*}{$\begin{array}{l}\text { B-14, } \\
17,18\end{array}$} & 100 & 38.01 & 65.68 & 2.65 & 3.011 \\
\hline & 150 & 20.82 & 30.8 & 3.2 & 3.44 & & 150 & 39.1 & 68.16 & 2.59 & 2.88 \\
\hline & 200 & 21.12 & 31.1 & 3.12 & 3.31 & & 200 & 40.11 & 70.52 & 2.54 & 2.78 \\
\hline \multirow{6}{*}{\multicolumn{6}{|c|}{$\begin{array}{l}\text { Notes: } \\
\text { 1. All the yield curvature values shall have } \\
\text { multiplied by } 10^{-3} \text {. } \\
\text { 2. Moment-Curvature values obtained from Section } \\
\text { Designer in Sap2000 software. }\end{array}$}} & \multirow[t]{3}{*}{ B-16 } & 100 & 39 & 92.8 & 2.62 & 3.28 \\
\hline & & & & & & & 150 & 40.05 & 96.52 & 2.57 & 3.10 \\
\hline & & & & & & & 200 & 41.05 & 100.4 & 2.55 & 2.98 \\
\hline & & & & & & \multirow{3}{*}{$\begin{array}{l}\text { B-19, } \\
20,21\end{array}$} & 100 & 36.24 & 36.24 & 2.70 & 2.70 \\
\hline & & & & & & & 150 & 37.50 & 37.50 & 2.66 & 2.66 \\
\hline & & & & & & & 200 & 38.63 & 38.63 & 2.56 & 2.56 \\
\hline
\end{tabular}

\subsubsection{Results of Columns-Interaction}

According to (Inel and Ozmen, 2006) study, three cases for transverse reinforcement spacing, $\mathrm{S}=100 \mathrm{~mm}, \mathrm{~S}=150 \mathrm{~mm}$, and $\mathrm{S}=200 \mathrm{~mm}$. Fig.9 showed the columns-interaction analysis result (Mohammed et al., 2018) for positive and negative regions. 

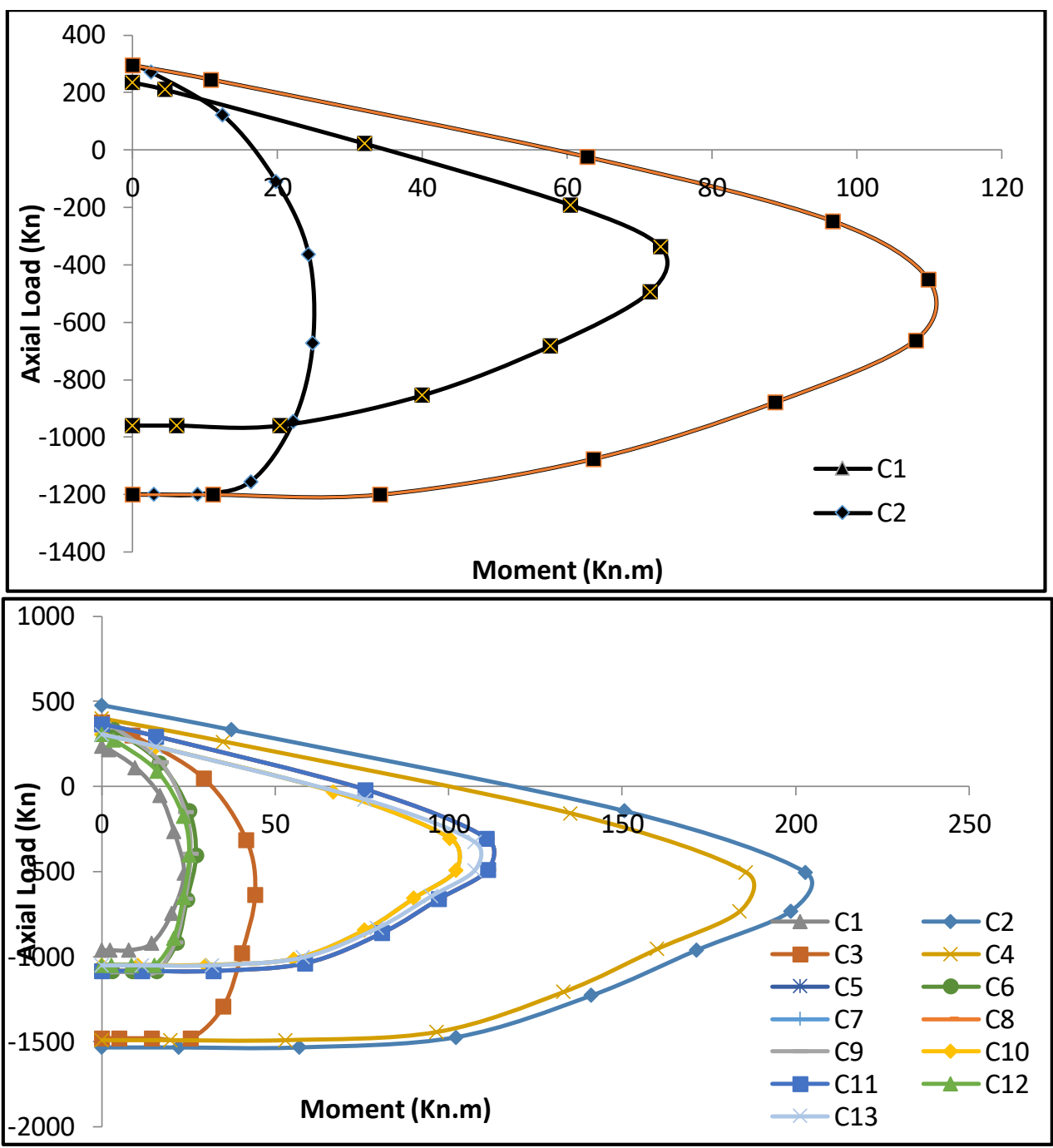

Figure 9. 4 \&7-columns interaction relationship.

\subsection{Properties of Nonlinear Plastic Hinges}

SAP2000 software required the moment-rotation instead of the moment-curvature relationship. Therefore, the rotation is measured by multiplying the curvature by the plastic hinge length, in this study, taken two expressions of the length of the plastic hinge into account. Equation (4) and Equation (5); $0.5 \mathrm{H}$ is the simplest plastic hinge length (Park and Paulay, 1975), and Equation (5) was proposed by (Priestly, et al., 1996).

$L_{p}=0.5 H$

$L_{p}=0.08 L+0.022 f_{y e} d_{b l} \geq 0.044 f_{y e} d_{b l}$

Where Lp is the plastic hinge length, $\mathrm{H}$ is the section depth, $\mathrm{L}$ is the critical distance from the critical section of the plastic hinge to the point of contraflexure, and $f_{y e}, d_{b l}$ are the expected yield strength and the diameter of longitudinal reinforcement, respectively. 


\subsection{Methodologies}

\subsubsection{Inel and Ozmen Methodology}

Inel and Ozmen study depended on the following assumptions:

- Based on (ATC-40,1996) and (FEMA-356, 2000), default hinges were assigned to the elements. For beams, $\mathrm{M}_{3}$ flexural hinges have been assigned at two ends. For columns, the interacting $\mathrm{PM}_{2} \mathrm{M}_{3}$ has been assigned at the upper and lower.

- In the user-defined hinge properties, the moment-rotation relationship reduced to five points only the positive points A, B, C, D, and E as shown in Fig. 10.

- Point B and C are related to yield and ultimate curvature. Point B obtained from SAP2000 using approximate component initial effective stiffness as the values in Table 2.

- Point $\mathrm{C}$ is the extreme curvature that described as the smallest curvature according to

1. A reduced moment equal to $80 \%$ of the maximum moment, calculated by the analysis of the moment curvature.

2.The extreme compression fiber reaching the ultimate concrete compressive strain, as determined by the simple relationship established by Priestley (Priestley, et al., 1996), given in Eq. 3.

3. The longitudinal steel reaches 50 percent of the capacity of the ultimate strain of the tensile strain corresponding to the monotonic fracture strain.

- Acceptance criteria are specified after calculating an element's ultimate rotation capacity, labeled IO, LS, and CP, Immediate Occupancy, Life Safety, and Collapse Prevention, respectively. It defines these three points as $10 \%, 60 \%$, and $90 \%$ of the use of plastic hinge deformation capacity.

\subsubsection{Methodology of the Current Study}

The current study depended on the following assumptions:

- Based on (FEMA-356, 2000) and (ASCE 41-13, 2014), default hinges were assigned to the elements. For beams, $\mathrm{M}_{3}$ flexural hinges have been assigned at two ends. For columns, the interacting $\mathrm{PM}_{2} \mathrm{M}_{3}$ has been assigned at the upper and lower.

- In the user-defined hinge properties, the moment-rotation relationship is defined to the positive and negative points A, B, C, D, and E, as shown in Fig.10.

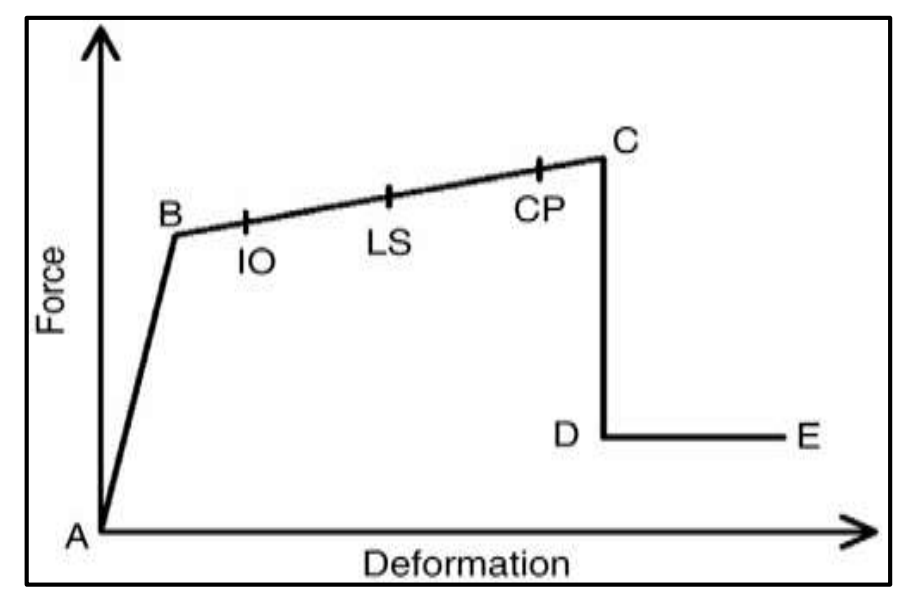

Figure 10. The relationship of a plastic-hinge Force deformation. 
- Points B and C are related to yield and ultimate curvature. The coordinates values of B, C, D, and $\mathrm{E}$ have been used in Table 6 (FEMA-356, 2000).

- Acceptance criteria are specified after the calculation of the ultimate rotation capacity of the elements. The coordinates values of performance level values have been used in Table 6 (FEMA$356,2000)$.

Table 6. Plastic Hinge Property for Sections.

\begin{tabular}{|c|c|c|c|c|c|c|c|}
\hline & \multicolumn{4}{|c|}{ Plastic Hinge Property } & \multicolumn{3}{c|}{ Performance Levels Values } \\
\hline \multirow{2}{*}{ Point } & \multicolumn{2}{|c|}{ Beams } & \multicolumn{2}{c|}{ Columns } & \multicolumn{2}{c|}{ Beams } & Columns \\
\cline { 2 - 5 } & Moment & Rotation & Moment & Rotation & IO & 0.01 & 0.003 \\
\hline A & 0 & 0 & 0 & 0 & & & \\
\hline B & 1 & 0 & 1 & 0 & LS & 0.02 & 0.012 \\
\hline C & 1.1 & 0.025 & 1.1 & 0.015 & & & \\
\hline D & 0.2 & 0.025 & 0.2 & 0.015 & CP & 0.025 & 0.015 \\
\hline E & 0.2 & 0.05 & 0.2 & 0.025 & & & \\
\hline
\end{tabular}

- Using Eq, 6, Eq.7, and Eq.8 the plastic hinges were placed at user-defined positions on the columns and beams.

$l_{l}=\frac{\mathrm{Lp}}{2}$

$l_{2}=\mathrm{H}_{\text {beam }}-\frac{\mathrm{Lp}}{2}$

$l_{3}=\frac{\text { Hcolumn }}{2}-\frac{\mathrm{Lp}}{2}$

where:

Lp is the plastic hinge length.

$\mathrm{H}_{\text {beam }}$ is the beam depth.

$\mathrm{H}_{\text {column }}$ is the column depth. 


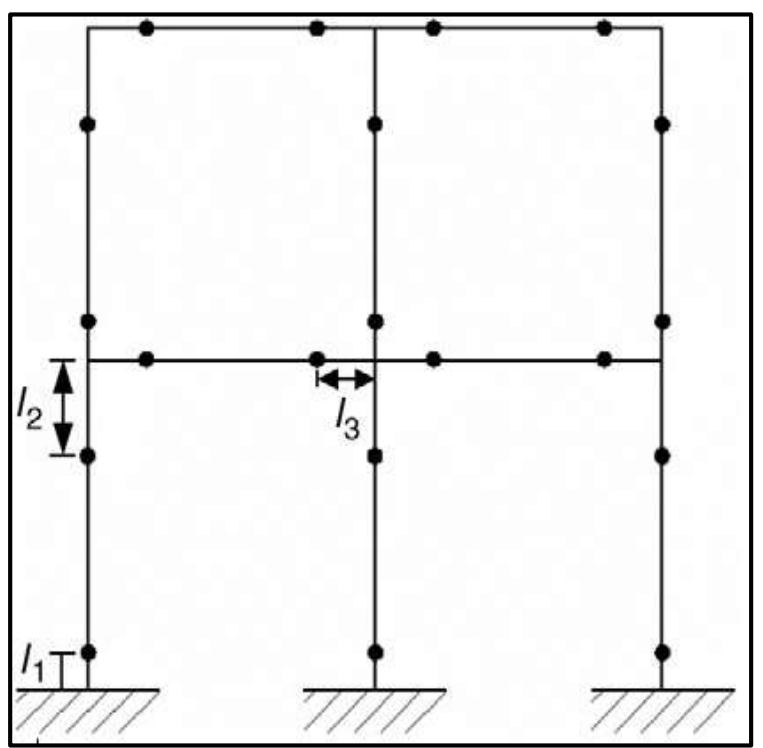

Figure 11. Hinge locations at the beams and columns.

- The shear strength of each member $\left(\mathrm{V}_{\mathrm{r}}\right)$ according to Turkish Standards Institute (TS500, 2000) which is related to Uniform building codes (UBC, 1988) as follows:

$V_{r}=V_{c}+V_{s}$

Where $V_{c}$ and $V_{s}$ are shear strengths provided by concrete and shear reinforcement by Eqs. (10) and (11), respectively:

$V_{c}=0.182 b d \sqrt{f_{c}}\left(1+0.07 \frac{N}{A_{c}}\right)$

$V_{s}=\frac{A_{s h} f_{y h} d}{s}$

where $\mathrm{b}$ is the section width, $\mathrm{d}$ is the effective depth, $\mathrm{fc}$ is the unconfined concrete compressive strength, $\mathrm{N}$ is the axial load on the section, Ac is the concrete area, and $\mathrm{A}_{\mathrm{sh}}$, and $\mathrm{f}_{\mathrm{yh}}$ are the area, yield strength, and spacing of transverse reinforcement, respectively.

4.8. Pushover Analysis

In the pushover analysis of each frame, five cases are considered, as shown in Table.7 Gravity loads were in place during lateral loading. In all situations, lateral forces were applied to monotonically forces in a step-by-step nonlinear static analysis. At each story level, the horizontal forces applied were proportional to the first mode shape amplitude under consideration and the product of mass. P-Delta effects have been considered. The structure behavior in pushover analysis is represented by a capacity curve. Pushover analysis results are discussed in the following:

Table 7. Pushover analysis cases.

\begin{tabular}{|l|l|l|l|}
\hline \multicolumn{4}{|l|}{ Default hinge (case A) } \\
\hline $\begin{array}{l}\text { User-defined } \\
\text { hinges }\end{array}$ & $\mathrm{S}=100 \mathrm{~mm}$ & $\mathrm{~S}=150 \mathrm{~mm}$ & $\mathrm{~S}=200 \mathrm{~mm}$ \\
\hline Lp /Eq. (4) & Case B2 & - & - \\
\hline Lp /Eq. (5) & Case B3 & Case C3 & Case D3 \\
\hline
\end{tabular}




\subsubsection{The capacity Curves}

Shear failure doesn't occur in all pushover analysis cases. Until if the shear steel spaces $200 \mathrm{~mm}$ the elements were able to strengthen the shear force. Shear failures usually occur in buildings with high spaces in shear reinforcement and with decreased concrete compressive strength. Fig. 12, Fig.13, and Fig.14, 4-and 7- story frame capacity curves are shown for various lengths of plastic hinge and spacing of shear reinforcement.
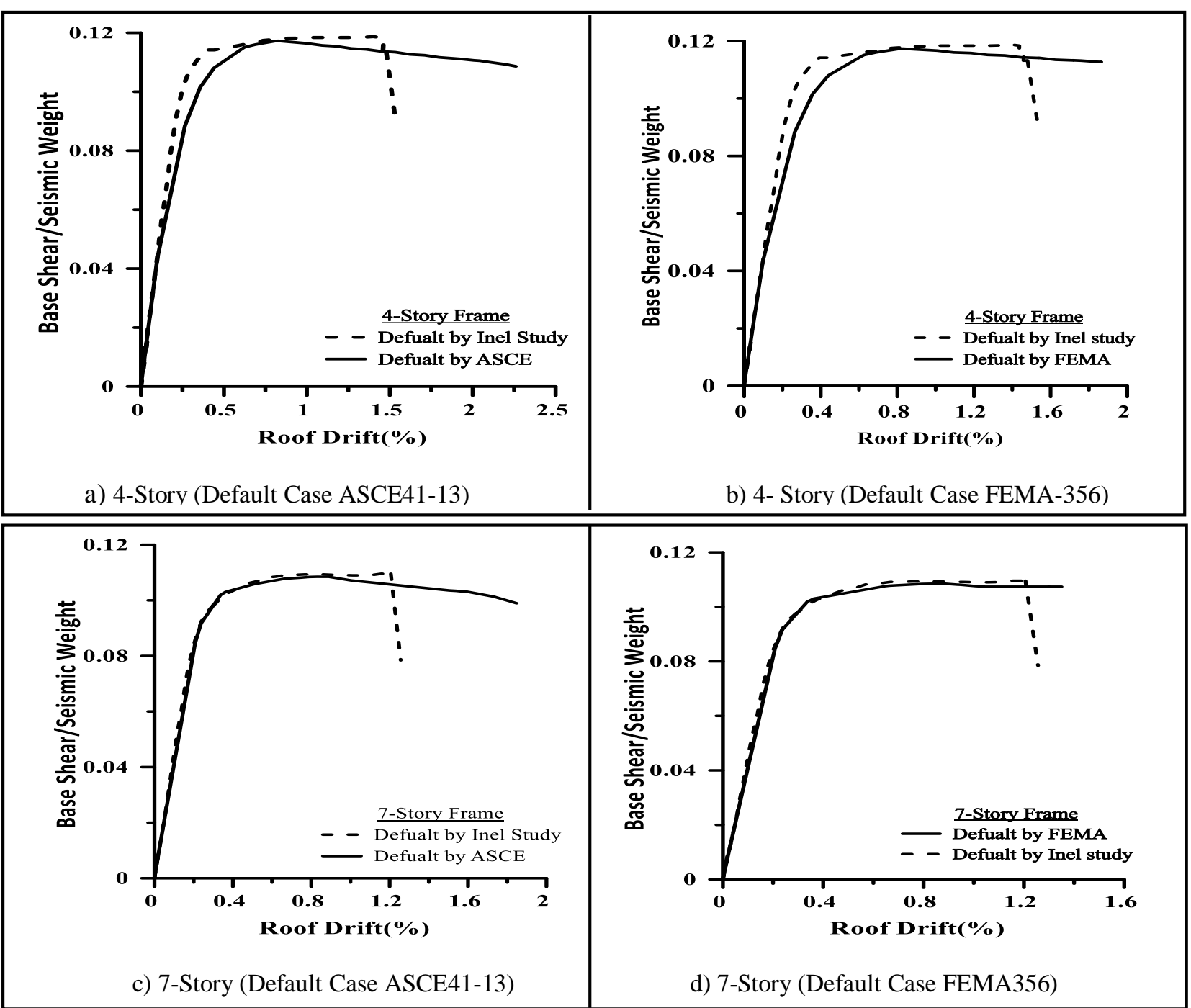

Figure 12. Verification of 4 and 7story frames capacity curves for Default Case.

Fig. 12 reveals the developments in the capacity curves of (Inel and Ozmen, 2006) study and the current study done for both frames. Case A represents the default values in SAP2000 based on (ASCE 41-13, 2014) tables. It also includes converting the (ASCE 41-13, 2014) values to the values listed in (FEMA-356, 2000). The aforementioned study indicates the results as hereinafter:

- For the current study, the base shear values converge substantially to (Inel and Ozmen, 2006) study for 4- and 7-story frames. 
- According to (ASCE 41-13, 2014), the values of roof displacement capacity increase by 46 percent to (Inel and Ozmen, 2006) study for 4- and 7-story frame Fig. 12 a and Fig. 12 c. The reason for this increase is that the collapse prevention level values (ASCE 41-13, 2014) reflect the ultimate capacity state of the section in the default hinge case.

- According to (FEMA-356, 2000), the values of roof displacement capacity increase by 20 percent to (Inel and Ozmen, 2006) study for both frames Fig. 12 b and Fig.12 d.

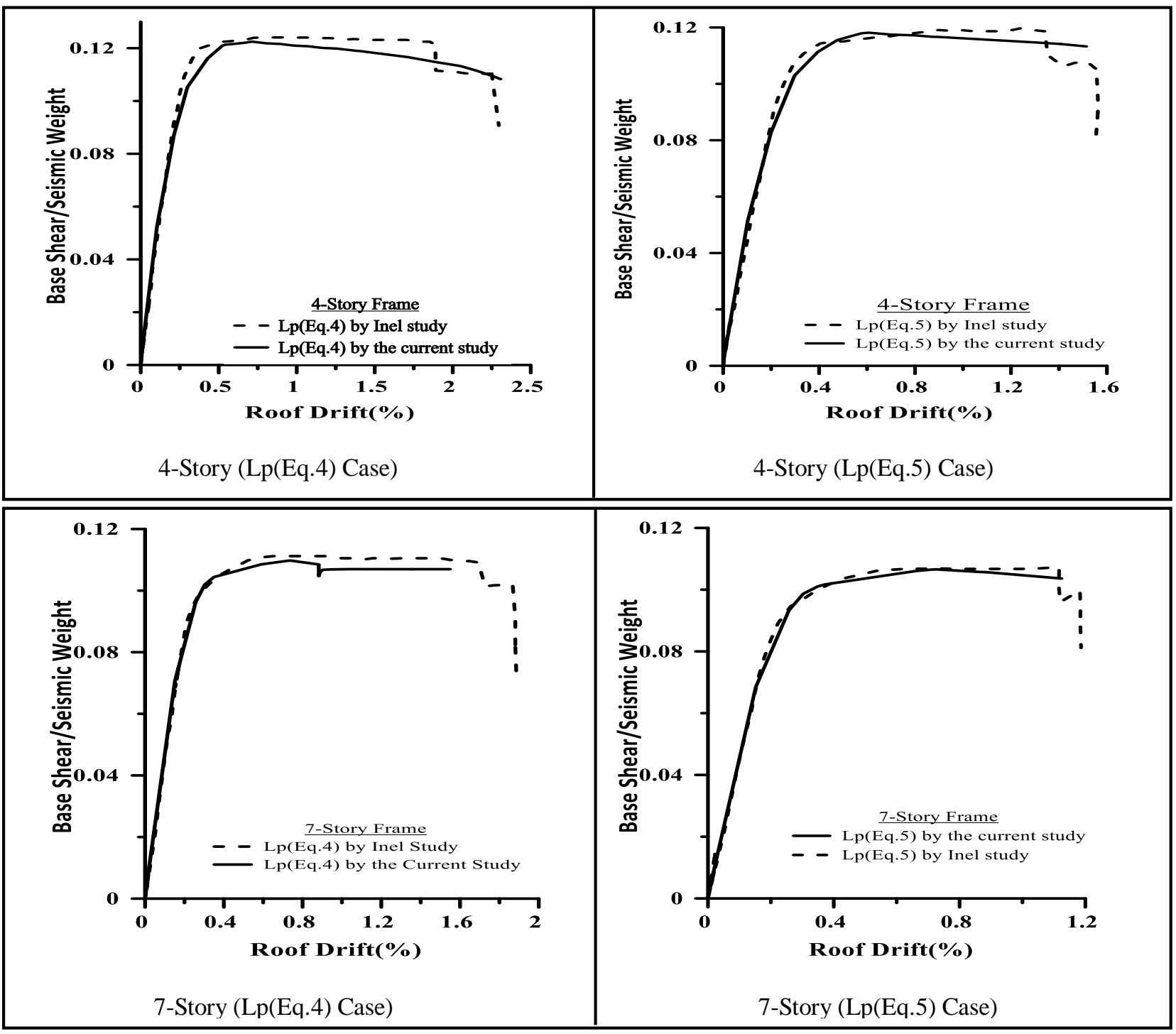

Figure 12. Verification of capacity curves of 4 and 7 story frames for various hinges. 

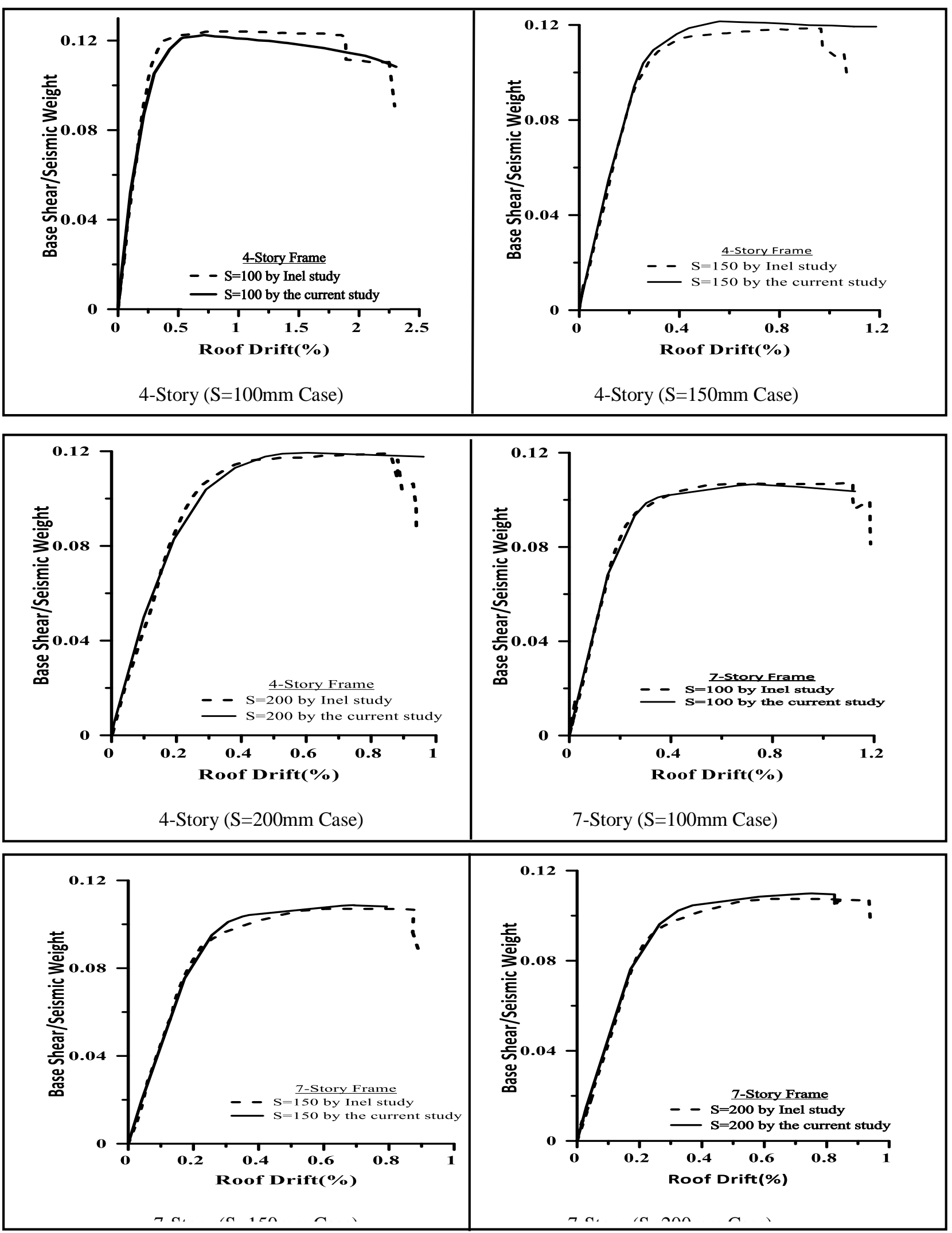

Figure 13. Verification of capacity curves of 4 and 7 story for various shear spacing. 
The trend of the capacity curves of the (Inel and Ozmen, 2006) study and the current study for both frames indicate that the values of base shear and roof displacement converge significantly. Fig. 13 and Fig.14, Base shear capacity is not dependent on the plastic hinge length and the transverse reinforcement spacing. Due to the plastic hinge location, the variation of the base shear capacity is less than 5\%. Fortunately, the plastic hinge length and the transverse reinforcement spacing significantly affect the frame roof displacement capacity. The displacement capacity is enhanced by increase the shear reinforcement. More effective if the spaces of the transverse reinforcement were smaller. The spacing reduction from $200 \mathrm{~mm}$ to $100 \mathrm{~mm}$ increases the displacement capacity by approximately 40 percent for a 4-story frame. The spacing reduction from $200 \mathrm{~mm}$ to $100 \mathrm{~mm}$ increases the displacement capacity by approximately 25 percent for a 7 -story frame. While the spacing reduction from $200 \mathrm{~mm}$ to $150 \mathrm{~mm}$ results in an improvement of only 12 percent for the 4 story frame, the spacing reduction from $200 \mathrm{~mm}$ to $150 \mathrm{~mm}$ results in an improvement of only 10 percent for the 7 story frame. Fig. 12 shows a difference by approximately 30percent in the displacement capacities of frames if Eq. (4) of plastic hinge length is used.

\section{CONCLUSIONS}

In pushover analysis, the current study for 4-and 7- story frames was selected to represent low and medium-rise reinforced concrete buildings. The frames were modeled with default hinge and userdefined hinge properties to examine potential variations in the pushover analyses results. The following conclusions were observed:

- Pushover analysis procedures were deemed to be a very practical tool for evaluating the nonlinear seismic performance of the structures. It introduced in this paper is a powerful tool for performance evaluation.

- The base shear strength does not affect by the plastic hinge length and the transverse reinforcement spacing.

- The collapse prevention level values of ASCE41-13 in SAP2000 software reflect the ultimate capacity state of the default hinge case. The collapse prevention level values given for ATC-40 and FEMA-356 are lower than the ultimate capacity case values. For this reason, ASCE41-13 gives displacement capacity larger than the displacement capacity with ATC-40 and FEMA-356

- The displacement capacity depends on the amount of transverse reinforcement. In particular, smaller transverse reinforcement increases the displacement capacity.

- The plastic hinge length has a considerable effect on the displacement capacity for both frames. Two expressions of Lp display that there is a difference in displacement capacities by approximately 30 percent.

- In describing nonlinear behavior compatible with element properties, the user-defined hinge model is better than the default hinge model. The consumer should be informed about what is given in the software, and avoiding the misuse of default-hinge properties is certainly relevant. 


\section{NOMENCLATURE}

$\mathrm{E}_{\mathrm{c}}=$ Modulus of elasticity of concrete .

$\mathrm{A}_{\mathrm{s}}=$ Area of concrete section resisting shear transfer

$\mathrm{A}_{\mathrm{g}}=$ Gross area of concrete section.

$\mathrm{B}=$ Section width.

$\mathrm{H}=$ Section depth.

$\rho=$ Ratio of tension steel area.

$\mathrm{IO}=$ Immediate occupancy.

LS $=$ Life safety.

$\mathrm{CP}=$ Collapse prevention.

$\varepsilon_{\mathrm{cu}}=$ Ultimate concrete compressive strain.

$\varepsilon s u=$ Steel strain at the maximum tensile stress.

$\rho_{\mathrm{s}}=$ The volumetric ratio of confining steel.

$\mathrm{f}_{\mathrm{yh}}=$ The yield strength of transverse reinforcement.

$f_{c c}=$ The peak confined concrete compressive strength.

\section{REFERENCES}

- Al Telbani, M., 2015. Seismic Resistance of Reinforced Concrete Buildings Designed for Gravity Loads in Gaza Strip, M.Sc. thesis submitted to Civil Engineering Department, the Islamic University - Gaza, Palestine.

- Bagchi, A., 2001. Evaluation of the seismic performance of reinforced concrete building, Ph.D., dissertation to Civil and Environmental Engineering, Carleton University, Ottawa, Canada.

- Bolander, J., 2014. Investigation of Torsional Effects on Thirteen-Story Reinforced Concrete Frame-Wall Structure Modeled in ETABS and SAP2000 Using Linear and Nonlinear Static and Dynamic Analyses, M.Sc. thesis submitted to civil engineering, University of California, San Diego.

- Chopra, A. K., and Goel R. K., 2002. A Model Pushover Analysis Procedure for Estimating Seismic Demands for Buildings, Earthquake Engineering and Structure Dynamics, 31:561-582.

- Durgesh C. R., 2005. Guidelines on Seismic Evaluation and Strengthening of Existing Buildings, Indian Institute of Technology Kanpur.

- Elnashai A. S., and Di Sarno L., 2008. Fundamentals of Earthquake Engineering. Wiley and Sons, UK.

- Erduran, E., and Yakut, A., 2007. Vulnerability Assessment of Reinforced Concrete Moment Resisting Frame Buildings, Journals of Structural Engineering, ASCE, Vol- 133, pp- 576-586.

- Fajfar, P., 2000. A Nonlinear Analysis Method for Performance Based Seismic Design, Earthquake Spectra,16:573-592. 
- Hede, N.P., and Bunarayan, K. S., 2013. Effect of Variation of Plastic Hinge Length on the Results of Nonlinear Analysis, International Journal of Research in Engineering and Technology, IC-RICE Conference Issue.

- Inel, M., and Ozman, H. B., 2006. Effects of plastic hinge properties in nonlinear analyses of reinforced concrete buildings, Engineering Structures, Vol. 28, pp. 1494-1502.

- Kasimzade, A., Nematli, E., Mammadzada,V., and Atmaca, G., 2020. New Design Criteria in Performance Based Earthquake Engineering, International Journal of Trend in Scientific Research and Development (IJTSRD), Vol: 4.

- Lee, D.G., Choi, W.H., Cheong, M.C., and Kim, D.K., 2006. Evaluation of Seismic Performance of Multistory Building Structures Based on the Equivalent Responses, Engineering Structure, 28:837-856.

- Mander JB., 1984. Seismic design of bridge piers, Research report 842: Department of Civil Engineering, University of Canterbury, Christchurch, New Zealand.

- Priestley M., Seible F., and Calvi G., 1996. Seismic design and retrofit of bridges, New York: John Wiley \& Sons.

- Park R., Paulay T., 1975. Reinforced concrete structures. New York: John Wiley \& Sons.

- Panandikar, N., and Narayan, K. S. B., 2015. Sensitivity of pushover curve to material and geometric modeling — an analytical investigation, Structures, vol.2, pp.91-97.

- Seneviratna, GDPK., and Krawinkler, H., 1997. Evaluation of Inelastic MDOF Effects for Seismic Design, John A. Blume Earthquake Engineering Center, Standford University.

- Salman, M. M., Jarallah, H. K., and Al-Behadili, R. S., 2018. Experimental Investigation of Short Square Normal and Hybrid Fiber Reactive Powder Concrete Columns Subjected to Chloride Solution Attack, Journal of Engineering, NO. 7, Vol. 24.

- Mahmoud, T. K., and Al-Baghdadi, H. A., 2018. Seismic Response of Non seismically Designed Reinforced Concrete Low Rise Buildings, Journal of Engineering, NO. 4, Vol. 24. 